\title{
Forensic excavations and burials in Uruguay, 2004-10
}

Jose López Mazz Universidad de la República en Uruguay

lopezmazz@yahoo.com.ar

\begin{abstract}
This article will describe the contemporary scientific techniques used to excavate and identify the dead bodies of disappeared detainees from the Uruguayan dictatorship. It will highlight the developments that have led to increased success by forensic anthropologists and archaeologists in uncovering human remains, as well as their effects, both social and political, on promoting the 'right to the truth' and mechanisms of transitional justice.
\end{abstract}

Key words: Uruguay, excavation, military dictatorship, pathology

In recent years, technical processes in forensic anthropology have led to major advances in solving political crimes and in shedding light on the human rights violations that were perpetrated in the second half of the twentieth century. This investigative strategy has improved the quality and reliability of information related to the whereabouts of disappeared detainees, the recovery of their remains, the identification of victims of state violence and the explanations of these crimes. In Latin America, a strategy that has brought together and combined processes, protocols and experiences from three different scientific areas has made it possible to consolidate a field of research into the heart of the region's problems. ${ }^{1}$

Firstly, a forensic archaeology has been developed that focuses on search techniques which optimise the chances of finding clandestine burials. At the same time, the delicate processes of forensic exhumation ensure that recovery is done in a proper manner - one that provides for maximum visibility of the human remains in terms of the bones (their position, state of preservation and so forth) and all the elements associated with the crime scene.

Secondly, forensic anthropology is employed, which aims to produce a biological profile of the skeletons and to recognise bone traumas that make it possible to identify perimortem injuries. Although a forensic anthropologist does not produce a pathophysiological report, he or she tries to come up with hypotheses regarding the causes of death that are reliable and supported by empirical evidence (in the bone traumas).

Thirdly, developments in human genetics have enabled a definitive advance in 
the quality of victim identification. In this way, we have been able to overcome the imperfect practices of the past, which did not provide the necessary guarantees, frequently resulted in confusion and caused a lamentable loss of trust in public services.

Moreover, the role of other disciplines such as social anthropology, history, sociology and political science has been essential in reaching a better understanding of the phenomena of political violence. ${ }^{2}$

In this article I will set out the work of the Forensic Archaeology Research Group (Grupo de Investigación en Arqueología Forense; GIAF) organised at the Institute of Anthropological Sciences of the University of the Republic's Faculty of Humanities and Education Sciences, which provided its services to the presidency of the Republic of Uruguay during the tenures of Dr Tabaré Vázquez (2005-9) and Mr José Mujica (2010-14). ${ }^{3}$ The cases studied are related to the crimes committed by the dictatorships of the 1970s in the Southern Cone (in Uruguay, from 1973 to 1984) and to activities carried out after the return to democracy from 1984.

At first, the investigation into the disappeared detainees led to a debate about the type of specialist who should carry out the search. It also created tensions between the professionals and technicians of the forensic services (part of the judicial authorities in Uruguay), both of whom, despite using out-of-date processes, claimed authority in matters of forensic expertise. The misuse of superimposed photos of skulls and victims produced countless errors that were soon revealed by DNA analysis. ${ }^{4}$ Designing a strategy that is capable of recognising political violence and mass crimes has therefore required the construction of a delicate balance between the knowledge and processes of the three specialisms mentioned above.

Protocols seek to improve the accuracy of the information produced, and also to minimise any vagueness and ambiguity. These procedural models drive the standardisation of practices, the goal being to guarantee a critical and homogeneous level of quality in all actions undertaken. Nevertheless, each case investigated has its own specific characteristics resulting from the unique nature of the criminal act, the profile of the perpetrators, the circumstances in which the incidents occurred, the political context and a varied spectrum of external causes. The conditions in which the search takes place are also a crucial part of the problem.

Recent experiences in Latin America have had positive results in respect of proceedings with a scientific basis, which have made it possible to clarify facts, fulfil the requests of families and identify the guilty. This has in turn improved the quality of justice in terms of both meeting the needs of the victims and finding the perpetrators responsible. However, and in spite of the scientific rigour of the processes used, excavation is not an instrumental activity that is justified of itself and in its own right (regardless of the political benefits that it produces).

A question mark hangs over the benefit of undertaking extensive and complicated archaeological excavations and thereby locating and exhuming victims, although I would first of all restate my firm conviction that excavation for the purposes of finding and exhuming victims is necessary. As the various experiences during this historic period demonstrate, we can expect a lot to result from a sufficient forensic working of the land. Carrying out forensic archaeological 
fieldwork necessarily involves making explicit a set of arguments and justifications that give purpose and meaning to the practice. Archaeological excavations and forensic exhumations are expensive, and one must be cautious with regard to the expectations that are placed upon them. They result in a set of discoveries - material and of various other kinds - that are capable of entering into a dialogue with the hypotheses of the criminal investigation, and archaeology has made great efforts to recognise and identify processes and relationships between human behaviour and its material products or consequences. Therein lies a specificity not offered by any other specialist: establishing 'archaeological facts' that, along with the judicial investigation, are capable of identifying contemporaneous systemic-functional relationships and certifying causal links between elements. ${ }^{5}$ By following procedures step by step, it has been possible to propose a working hypothesis to understand the violence in terms of the links between the protagonists, the evidence recovered and the circumstances of the events.

Excavation is an activity that transforms an ordinary location of no interest into a crime scene. But the route leading from excavation to exhumation is long and tedious, as well as full of unforeseen events and bureaucratic proceedings. It is therefore necessary to make explicit the reasons for, and the good intentions behind, deciding that excavating is the right way to deal with a tangible problem within a given judicial time frame. At the same time, the most appropriate procedures and tools must be chosen, and a meticulous recording of all findings must take place. Indeed the strength of the practicelies in its controlled observation.

When the remains and evidence of a crime (denied until then) are recovered, excavation and exhumation restore a place's historical identity and reveal facts that were previously unknown. Because citizens' experiences are often linked to the restitution of a historical memory of extreme violence in these areas, a wide range of sectors of society spontaneously appropriate the discoveries of the remains of disappeared detainees. ${ }^{6}$ The excavated places acquire prominence and various meanings are projected onto them. 'Memorials' and museums of violence and memory are created as an educational strategy to reflect on certain values and as a way of guaranteeing that the past will not be repeated.

In Uruguay, the search for the disappeared generated useful information for discovering the personal itineraries of the disappeared themselves, and helped to supply answers to unresolved questions for the affected families. But it also contributed decisively to the historical memory of a whole society that is still suffering from a long process of decolonisation, a society that needs to know more about its recent history.

\section{Why excavate?}

Before archaeologists answer the question of how to excavate, they must justify why they should do so in the first place: excavation is a key stage of an investigation because, from the actions that are being studied, it generates information that is fresh, clean, independent, reliable and direct.

We need first to define the exact scope of the concept of 'excavation'. In a strict 
sense, 'excavating' means removing sediment to facilitate the localisation and then the exhumation of objects, human bones and remains, and also to enable the observation and recording of stratigraphy. This work of systematic, controlled observation produces direct in situ proof that allows - based on a detailed study of the associations and arrangements of the elements located - the natural and cultural processes that occurred in each case to be recognised, along with their scope and some indicators that allow temporal factors to be evaluated.

It is more generally accepted, in line with the heritage and cultural interest of locations (UNESCO), that 'excavating' refers to all fieldwork, including exploratory stages prior to identifying the site (survey or exploration). This general understanding includes direct sampling of locations that does not necessarily involve the movement of earth (rock tracing, infrared photos, digital models, systematic studies of aerial photography, studies of the vegetation and so forth). What may at first be just an anomaly in an aerial photo or an insignificant discovery (everyday objects or ephemeral remnants) may turn out to be the clue that effectively locates a site for fieldwork. These clues may later attain the status of conclusive evidence used in charges or a prosecution. But only the shared efforts of the investigative process involved in a legal case and of the archaeological/forensic search (on a different scale) can definitively identify the evidence, its scientific nature, its legal status and its demonstrative significance, all of this being carried out within the framework of a concrete hypothesis. It is true that objects do not speak for themselves, and it is within the framework of explicit methodological and technical procedures that evidence takes on its critical meaning.

The act of removing earth to exhume bones and objects and to observe strata of the subsoil is the central business of archaeological fieldwork. It is worth repeating, however, that excavation is not an activity that can be justified for its own sake, but a major process of work that is undertaken to construct a rational account of, and provide answers to questions related to, past events. This chain of evaluation attempts to produce specific information for each of the successive stages of an investigation. Sometimes the investigations of the justice system and those of forensic archaeology seem to run on parallel lines. However, it is the appropriate and timely combination of these two lines of work that provides a mutually related identity.

In the majority of cases, a search excavation and scientific exhumation remain the only way of establishing facts relating to disappeared persons. In these scenarios the information generated by this well-refined procedure is generally more reliable than that produced by other strategies. For instance, geophysics, which has provided good results in other places, could not be used in wooded areas prone to flooding, which is where most of the searches in Uruguay were carried out.

Here, locating the bodies of disappeared detainees required a systematic search operation over large areas. This 'archaeological prospecting' often proved to be more effective than any speculation based on oral testimony. In Uruguay, oral testimony (especially that of the military) as strategic evidence was insufficient, imperfect, biased, subjective or completely false. When a witness provides testimony, he or she says it at the expense of many things that he or she does not say. ${ }^{7}$ The lack of 
documentary information and the weakness of the oral testimony required the use of ethnographic techniques for the collection of tesimony, but this did not guarantee success in a search operation.

An internal investigation conducted by the Uruguayan army provided information concerning the location of buried persons disappeared in Argentina which considered by the government to be extremely reliable. ${ }^{8}$ Archaeological procedures showed this information to be false. When confronted with the 'nondiscovery' at the indicated locations, the same military sources said that the skeletal remains had been removed as part of a 'clean-up' operation on the eve of the return to democracy. An analysis of all the strata making up the piece of land in question indicated that no one had ever been buried there, as the earth strata were completely undisturbed. In this case an archaeological study of the sediments was more eloquent than a thousand words. It was able to prove concretely that the information supplied (about the burial and its clandestine exhumation) was false and that it was an act of counter-information intended to mislead the search.

\section{Where to excavate?}

Excavation and then exhumation are activities preceded by decisions that justify the task and make it physically possible. The locations of the incidents, the crime scenes, require a prior process of documentary and testimonial analysis so as to provide geographical identity and historical authenticity. Establishing the sites for archaeological excavation then needs rigorous research, as today, nearly forty years after the events, the locations of clandestine burials are still the subject of continuous and active acts of concealment. Although many years have passed since the political crimes in Uruguay, precise information on the locations where the disappeared detainees were buried is almost non-existent. This silence is part of the continuing strategy of denial of facts.

Precise information on a location in which to excavate may come from the eyewitness testimony of an incidental protagonist. In many cases, the selection of a geographical location is part of a much longer process that begins with some vague or indirect testimony, leads to successive stages of study through aerial and land photographs and finally raises hopes of a more concrete delimitation of 'places'. Once a geographical space was selected from a major area that had been previously studied, we were able to carry out extensive search excavations and finally locate a burial and perform an exhumation. The construction of a coherent chain of evaluation ensures that the investigation moves successfully from one stage to the next. It is through careful and systematic treatment of this flow of information that the probability of making a discovery increases.

The size of the search area was one of the major challenges of the archaeological fieldwork. To tackle dozens of hectares, it was strategically necessary to choose a set of techniques that would increase the probability of a discovery. The scale of the subject (individual graves, communal burial pits or clandestine cemeteries) is also a strategic factor in demarcating an area to be investigated.

Yet systematic work cannot protect investigators from some of the unforeseen 
factors that are typical of these postdictatorship scenarios: the external threat resulting from a deliberate process that is intended to mislead the case. It is not paranoid speculation to perceive intentional obstruction of the work carried out by archaeological teams and of the justice system itself. On the contrary, these situations form part of the complex political context in which, even during the democratic era, witnesses of state terrorism in Argentina are still abducted and, in Uruguay, the army supplies false information to the president.

When the results of an excavation confirm that the right place has been located, a new process - one of adding history to geography, and memory to place - can begin. Such a process may be initiated by the ruling of a judge or a human rights NGO, but a spontaneous process of appropriation of the locations by different sections of society can also take place.

Prior to the return to democracy, an extensive search for bodies was conducted by the military within the headquarters of Parachute Battalion No. 14. The process of research and evaluation described above revealed that this work had altered the landscape of the area. Near this area, two bodies were found by the GIAF that appeared to have escaped from the military operation of destruction. In 2014, at the request of the Commission for Cultural Heritage of the Nation of Uruguay, the Minister of Education and Culture declared the land of Parachute Battalion No. 14 (Toledo, Canelones) a National Historic Monument, the remains of several disappeared detainees from the military dictatorship having been found there. ${ }^{9}$

\section{How to excavate?}

The answer to this question varies greatly and is directly related to the physical characteristics of the location, together with the guidelines for the work, the hypotheses being followed and the elements being sought. Classical archaeological techniques have developed various strategies for clearing the earth and recording and exhuming remains in a controlled manner. ${ }^{10}$ Archaeology's classical objects of study have varied in size from the cities of classical antiquity, through to Neolithic settlements and, finally, to a very careful focus on the prehistoric habitat of Palaeolithic man.

Starting from these classical procedures, archaeologists select the means that are best suited to the subject that they are studying. Generally speaking, the techniques applied to prehistory, being particularly careful, are most suited to the exhumation of sets of human skeletal remains and clandestine tombsThese techniques, as well as being painstaking during the removal of sediment and requiring the use of delicate tools, have led to the development of systematic control of the findings so as to produce exhaustive records. The precision of these records, with spatial (and positional) measurements and stratigraphic contexts with three-dimensional measurements, creates very eloquent graphic representations (excavation plans). On these plans, associations and overlaps, which are the type of links between exhumed elements, can be better discerned. All this information makes possible the identification of contemporaneity between elements. The association of contemporaneity itself is what suggests a causal relation between elements (for example, a skeleton 
with ballistic projectiles or covered in quicklime). Once a type of association is identified, its reoccurrence in other places confirms a recognisable pattern, a key element in the criminal investigation that can guide the judge in his or her own deliberations and interpretation.

In some cases, the size of the area chosen has a critical influence on the choice of procedures and the most appropriate tools. This happens especially when the stage prior to excavation has not produced any very specific results and the excavation has to be extended over a very large area. During work in Uruguay it was necessary to deal with an area of dozens of hectares, and the only method available was to use a backhoe loader. This option presents the risk of damaging a bone when a discovery is made. But, when faced with the vagueness of the data and the need to search over huge areas, the risk of damaging a bone is minor compared to the risk of not finding anything. With a backhoe loader, it was possible to achieve an average of $250 \mathrm{~m}^{2}$ per day and tackle a large area at Parachute Battalion No. 13. It would have been impossible to do similar work in the same time using manual techniques, and the timetable for each technical procedure is no small consideration in archaeological work. Time factors related to the legal system, witnesses and, above all, access to work areas can combine to make difficulties in carrying out a schedule of work and achieving the objectives within the allocated time.

In some cases, the characteristics of the places have a huge influence, to the point where they cast doubt on the very possibility of carrying out an archaeological excavation, for physical and mechanical reasons. This impossibility has indeed arisen as many complex strategies of concealment have become apparent. In the most notable cases, buildings have been renovated or even deliberately built over areas where burials are located; such extreme cases make it virtually impossible to carry out a search excavation or an exhumation.

Another factor to be taken into account relates to the attention that family members require during the exhumation processes. ${ }^{11}$ Leaving aside its strictly technical aspects, excavation sets up expectations in people who have suffered greatly, and here forensic archaeology requires a strategic link with psychology. Experience tells us that we must be aware of this human dimension of the scientific work and avoid mistakes made in good faith.

\section{When to excavate?}

The point at which a forensic excavation would be carried out in the search for disappeared detainees was affected by three key circumstances. The first stemmed from the ruling and/or authorisation of the judge on the cases under investigation. In Uruguay, the initial investigations considered the quality of the information, which in itself could justify an excavation. As a result of the false information supplied by the military authorities, mentioned earlier, the investigations gradually became entirely the subject of legal cases.

Combined with the above circumstance, approval for an excavation is also affected by the point at which the investigator judges it opportune to be undertaken, within the general context of the developing investigation. This also relates 
to the general scheduling of fieldwork and the time when the investigator can have available the technical tools, human resources, logistical arrangements and necessary coordination. Excavating on military land poses a set of delicate circumstances that must be considered. In such cases, coordinating the work with the judge is essential.

Perhaps the key and best moment to carry out an excavation is when the investigators have acquired sufficient elements of certainty and the evaluation of previous activities has accumulated information of sufficient precision and quality to increase the chances of making a discovery. Every investigation has its own dynamic and rhythms arising from the verification scenarios that the investigator has drawn up. Working hypotheses are built around an accumulation of quality information that gives credence to the explanation of the events being studied. In general, the exhumation of human remains is the final activity of the fieldwork. Prior to that, there are intermediate stages of extensive excavation in which the investigator finds specific elements of partial confirmation of the information that he or she is handling.

There were also times when the investigation required excavation work that did not directly aim for the recovery of human skeletal remains, but that was intended to test the quality of the information that was being handled. This occurred in relation to a 'clean-up' operation of the clandestine cemeteries that the Uruguayan military had carried out between 1983 and 1985, on the eve of the return to democracy. 'Operation Carrot' - so called by the repressors - was intended to destroy or permanently conceal evidence of the bodies, in the light of imminent legal cases that were set to take place with the return to democracy.

During the first Peace Commission (2000) the military used this operation to argue for the futility both of searching for disappeared detainees and, even more so, of any attempt to recover their remains. This operation to destroy the skeletal remains in the clandestine burial sites became a working hypothesis, which itself required excavation work in order to search for empirical support for such a version of events. The methodological scenario for validation that was proposed for this hypothesis focused the search on material features, in line with the testimony that had been collected. ${ }^{12}$

Information on the destruction of bodies varied in kind, and came from highranking military sources as well as from soldiers who took part in the violence or were witnesses. The investigation eventually reached a point at which it was decided to carry out excavations as the only means to produce proof that would either confirm or refute the information. The excavations conducted in the areas indicated by the witnesses (generally low-ranking soldiers) made it possible to locate and identify stratigraphic anomalies in the layers of subsoil, isolated pieces of human skeletons and tracks that clearly matched the type of machine used, as described by the witnesses.

It is certain that the scope of the operation to exhume and destroy bodies had been limited and had reached only those burials that were easiest to access, or about whose location the military still had information. Nevertheless, the decision to use archaeological excavation, combined with aerial photography, to confirm 
the fact of the operation proved correct, as it provided greater empirical support as well as greater rigour to the whole investigation. ${ }^{13}$

The clandestine burial of bodies by the military met its empirical match in the stratigraphic expertise of the archaeological excavation. Independent information comprising the discovery of partial skeletal remains in the same locations was found to be compatible with information from the excavation. In line with the military's wish to continue to conceal the disappeared, in 1983 the 'unidentified' human remains that were in various cemeteries (Rocha, Maldonado, Nueva Palmira and Montevideo) were sent to ossuaries to avoid any identification.

\section{Discussion and conclusions}

Time is the enemy of memory as the earth swallows up the disappeared. The archaeologist is a geologist-cum-obstetrician who helps to bring memory back to life when it has lain in oblivion. The forgotten, the disappeared and the vanquished bring their own history to life as they spring out and re-emerge from things and places. However, the benefit of search excavations and forensic exhumation in scenarios of political violence has been a subject of debate and political speculation. But where a search excavation has not yet taken place, it constitutes a story yet to be told, and no one can, a priori, over-estimate its revelatory effect. Forgotten history - the making visible of what was intended to be hidden, the location of what was thought lost forever - responds decisively to archaeological excavation in forensic scenarios.

Yet, although an archaeological excavation has much to offer in the search for evidence to shed light on cases of political violence, the role of the archaeologists themselves can be much more ephemeral and vulnerable. They do not have the power of the politician who orders and/or demands the excavation, or the strength of the military or the police who resist investigations through their silence.

Excavation is also used, as we have seen, to detect lies when false information is given, as in the case of the disappeared detainees. The remains of some of the disappeared were not where the military indicated; but, above all, it was proved that they had never been there at all. ${ }^{14}$ This this case excavation was able to provide evidence of of a counter-information operation, carried out more than thirty years after the return to democracy. We could never have imagined such an overwhelmingly convincing result. Exhumation is used to recover bodies with the meticulous care that is necessary to uncover the torture suffered by the disappeared detainees and to support doctors in identifying the causes of death.

In addition to supporting reparatory political and legal advances, excavation has benefited the 'right to truth' and the supplying of quality information for the purpose of administering justice. Furthermore, it has also made it possible to ensure, among other things, a human right that should exist in international agreements: a dignified burial. Exhumation is used to support fundamental practices, such as for a son to be able to bury his father, or a father to bury a son.

Excavation is also used to clarify other various instances of political repression, such as the concealment and destruction of human remains. It helps to uncover the 
strategies used to deny crimes against humanity, and to shed light on dark episodes of political repression; it helps to write recent history, one spadeful at a time.

However, just as the answer to one problem is found, another problem may appear. This was the case with the clandestine exhumation (and possible reburial) of bodies carried out by the military between 1983 and 1985 .

This repressive and clandestine operation has postdictatorship similarities to 'Operation Condor' - a concern to keep disappearing the disappeared, combined with a criminal use of technology such as backhoe machines in 'Operation Television Removal' as carried out in Chile, ${ }^{15}$ and in 'Operation Carrot' in Uruguay. ${ }^{16}$ Investigations into this matter also suggested a pact between the military and civilians for the restoration of democracy. In this situation the bodies of the disappeared detainees were viewed as an obstacle to the political agreement known as the 'peaceful transition'. ${ }^{17}$ Even after death, the disappeared continued to create strong opposition.

The return to democracy in the Southern Cone countries of South America was achieved by setting up a system of transitional justice in relation to the violations of human rights. In this context, the extensive archaeological search excavations and the forensic exhumations were the pillars of a transitional science that supported the political process and helped to solve some of its central problems, revealing their engagement with history. Places linked to crimes and political violence are now identified in the social imagination. When archaeological excavation succeeds in exhuming horror, the first stone is laid for the foundation of places of memory and evocation. In these incidentally archaeological scenarios, various social appropriations of the past take place. Despite the conflict between sectarian groups who claim exclusive rights over the political life of the dead, a process of making the locations of political violence into places of national heritage is important. In different ways, society requires that historical memory be memorialised and taken forward into the future. ${ }^{18}$

The proposal for this designation emphasised the significance of the site in Uruguay's social memory, its value as a territorial 'marker' and a strategic place of historical and moral reflection. The line taken by the public policy of the CNPC therefore promoted a distortion of the political crimes, as public involvement with the material aspects of the archaeological investigation establishes a new stage in their management; by locating and exhuming the remains of the disappeared, forensic archaeology also confers upon them a new political life. ${ }^{19}$ But, both in the resolute search for the disappeared and in the responsible management of the findings, scientific, ethical, legal and political dialectics persist, giving social meaning and rationality to subjects, objects and places of violence.

\section{Notes}

1 L. Fondebrider, 'Arqueología y Antropología Forense: un breve balance', in P. Funari and A. Zaranin (eds), Arqueología de la represión y la resistencia en América a Latina (Córdoba, Encuentro Grupo Editor, 2006), pp. 129-38;

M. Somigliana, 'Materia oscura, los avatare de la antropología forense', in 
A. Zarankin, M. Salerno and M. C. Perosino (eds), Historias desaparecidas: arqueología, memoria y violencia política (Córdoba, Encuentro Editores, 2012), pp. 25-34.

2 A. Rico (ed.), Historia reciente, historia en discusión (Montevideo, CEIU/UdelaR/ PNUD, 2008).

3 J. López Mazz and A. Lusiardo, 'The Developement of Forensic Archaeology and Anthropology, by the Uruguayan Forensic Anthropology Team', in N. MárquezGrant (ed.), Forensic Archaeology: A Global Perspective (Chichester, WileyBlackwell, 2015).

4 Y. Memhet, H. Solla and B. McCabe, 'Victimes of Dictatorial Regime: The Identificación of Gomensoro', Forensic Science International, 30 (2005), 1-8.

5 P. Courbin, Qu'est ce que l'archéologie? (Paris, Payot, 1982).

6 J. López Mazz, 'Historias desaparecidas y re aparecidas: el caso uruguayo', in A. Zarankin, M. Salerno and M. C. Perosino (eds), Historias desaparecidas: arqueología, memoria y violencia política (Córdoba, Encuentro Editores, 2012), pp. 45-60; J. López Mazz, 'Archaeology of Historical Conflicts, Colonial Oppression, and Political Violence', in A. González-Ruibal and G. Moshenska (eds), Ethics and the Archaeology of Violence (New York, Springer, 2014), pp. 71-88.

7 M. Foucault, El orden del discurso (Barcelona, Tusquets, 1999 [1973]).

8 J. López Mazz (ed.), Investigaciones arqueológicas en busca de los detenidos desaparecidos, vol. 5 (Montevideo, Presidencia de la República, IMPO, 2005).

9 Comisión del Patrimonio Cultural de la Nación. 2014. Ref. Exp.2014-11-0008-0201.

10 E. Harris, Principios de estratigrafía arqueológica (Barcelona, Crítica, 2001).

11 P. Perez-Sales and S. Navarro García, Resistencia contra el olvido: trabajo psicosocial en procesos de exhumaciones (Barcelona, Gedisa, 2007).

12 J. López Mazz et al., Investigaciones arqueológicas en busca de los detenidos desaparecidos (Montevideo, Presidencia de la República, IMPO, 2010-13); V. Martínez, 2009. Las manos en la tierra. Film, $35 \mathrm{~min}$. Film doceumental. TNU/ Ibermedia/Fona, Montevideo $45 \mathrm{~min}$. Montevideo.

13 López Mazz, 'Archaeology of Historical Conflicts'.

14 López Mazz et al., Investigaciones arqueológicas.

15 I. Cáceres, 'Chile: Operación “retiro de televisores”: desaparecer a los desaparecidos', in A. Zarankin, M. Salerono and M. C. Perosino (eds), Historias desaparecidas (Córdoba, Editora Brujas, 2012), pp. 61-78.

16 López Mazz et al., Investigaciones arqueológicas.

17 A. De Giorgi, Sanguinetti: La otra historia del pasado reciente (Montevideo, Fin de Siglo, 2014).

18 López Mazz, 'Historias desaparecidas'.

19 K. Verdery, The Political Lives of Dead Bodies: Reburial and Postsocialist Change (New York: Columbia University Press, 1999). 